University of Rhode Island

DigitalCommons@URI

Open Access Master's Theses

1978

\title{
AN EXPERIMENTAL MODEL OF HEPATIC FIBROSIS INDUCED BY THE ADMINISTRATION OF DIBUTYLTIN DICHLORIDE
}

Jeannee Karen Yermakoff

University of Rhode Island

Follow this and additional works at: https://digitalcommons.uri.edu/theses

\section{Recommended Citation}

Yermakoff, Jeannee Karen, "AN EXPERIMENTAL MODEL OF HEPATIC FIBROSIS INDUCED BY THE ADMINISTRATION OF DIBUTYLTIN DICHLORIDE" (1978). Open Access Master's Theses. Paper 230. https://digitalcommons.uri.edu/theses/230

This Thesis is brought to you for free and open access by DigitalCommons@URI. It has been accepted for inclusion in Open Access Master's Theses by an authorized administrator of DigitalCommons@URI. For more information, please contact digitalcommons-group@uri.edu. 
AN EXPERIMENTAL MODEL OF HEPATIC FIBROSIS

INDUCED BY THE ADMINISTRATION OF

DIBUTYLTIN DICHLORIDE

BY

JEANNEE KAREN YERMAKOFF

A THESIS SUBMITTED IN PARTIAL FULFILLMENT OF THE REQUIREMENTS FOR THE DEGREE OF

MASTER OF SCIENCE

IN

PHARMACOIOGY AND TOXICOIOGY

UNIVERSITY OF RHODE ISIAND

1978 


\section{MASTER OF SCIENCE THESIS \\ OF \\ JEANNEE RAREN YERMAROFF}

Approved:

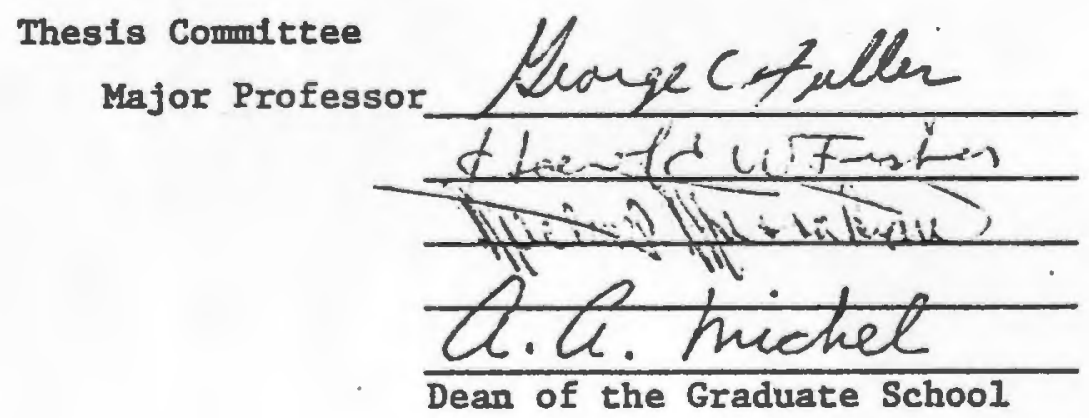

UNIVERSITY OF RHODE ISLAND

1978 


\section{ABSTRACT}

Yermakoff, Jeannee Karen. M.S., University of Rhode Island, 1978. An Experimental Model of Hepatic Fibrosis Induced by the Administration of Dibutyltin Dichloride. Major Professor: Dr. George C. Fuller.

Dibutyltin dichloride (DBT), one of a series of dialkyltin derivatives used industrially as polyvinylchloride stabilizers and urethane catalysts, was investigated for its ability to induce liver fibrosis in rats.

Collagen, the predominant protein in fibrotic tissue, is synthesized in a series of sequential steps consisting of assembly of a proline-rich and lysine-rich polypeptide precursor of collagen, enzymatic hydroxylation of some of the prolyl and lysyl residues, and glycosylation of some of the hydroxylysyl residues. Since prolyl residues are not hydroxylated before they are in peptide-bound form, the conversion of isotopically labeled proline to hydroxyproline by prolyl hydroxylase was taken as one parameter reflecting the rate of collagen formation. In vitro collagen synthesis was determined by incubation of liver biopsies with labeled proline, after which incorporation of label into collagenase digestible protein is compared to incorporation into collagenase-resistant protein. Hydroxyproline content served as a parameter of increased collagen accumulation, since hydroxyproline does not appear in significant amounts in noncollagen protein. 
DBT was administered by oral intubation ( 10 and $20 \mathrm{mg} / \mathrm{kg}$ ) every other day for 12 days. Histopathological observation in these rats revealed extensive inflammation in portal tracts, bile duct inflammation and proliferation, fibrosis, necrosis, infarcted areas and granulomatous lesions. In the higher dose group, a greater than two-fold increase in hydroxyproline content, a greater than $50 \%$ increase in prolyl hydroxylase activity and a two-fold increase in relative collagen synthesis in vitro was observed at the end of the 12 day period.

DBT, administered by oral intubation (10 and $20 \mathrm{mg} / \mathrm{kg}$ ) daily for four days, produced inflammation of portal tracts and bile duct inflammation and proliferation. Prolyl hydroxylase was increased 50 and $130 \%$ over control values in the 10 and $20 \mathrm{mg} / \mathrm{kg}$ groups, respectively. In vitro collagen synthesis increased approximately five-fold in the higher dose group. However, there was no increase in relative collagen synthesis due to a concomitant elevation in noncollagen protein, probably as a result of inflammatory cell protein synthesis.

DBT $\left(3 \times 10^{-7}\right.$ and $\left.3 \times 10^{-6} \mathrm{M}\right)$ had no effect on prolyl hydroxylase activity of L929 mouse fibroblasts in cell culture. 


\section{ACKNOWLEDGEMENTS}

The author wishes to express her sincere appreciation to Dr. George C. Fuller for his guidance and inspiration throughout the course of this investigation. Thanks is also extended to the members of her committee and the faculty of the Department of Pharmacology and Toxicology of the University of Rhode Island for their assistance. The help and support of her fellow graduate students, which has been invaluable, is gratefully acknowledged. Gratitude is extended to Dr. Jesus V. Rodil for his proficient histological evaluation of tissues described herein. The author sincerely thanks Ms. Regina White Santos and Mrs, Nadylis Wood for their skillful technical ass istance.

The author wishes to express sincere appreciation to her parents, Serge and Mildred Yermakoff, for their continued support, encouragement and understanding during her academic career.

The author acknowledges the financial support provided by Teaching Assistantships from the Department of Pharmacology and Toxicology and the Graduate School Affirmative Action Program. This investigation was supported in part by a grant awarded to $\mathrm{Dr}$. George C. Fuller from the National Institute on Alcohol Abuse and Alcoholism (AA 01422). 
To the Late

Simon Matthew Yermakoff 
TABLE OF CONTENTS

ABSTRACT ................. . . ii

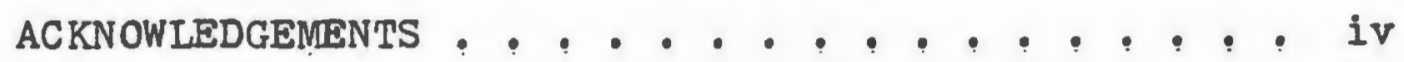
DEDICATION . . . . . . . . . . . . v TABLE OF CONTENTS .............. . . vi LIST OF TABLES . . . . . . . . . . . . viii IIST OF FIGURES . . . . . . . . . . . . . ix INTRODUCTION .............. I 1 LITERATURE SURVEY . . . . . . . . . . 3

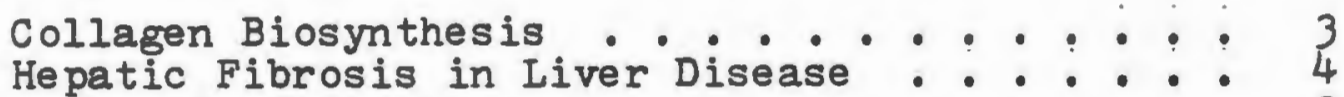
Organotin Toxicity ............ 8 EXPER IMENTAL . . . . . . . . . . . : 12 Animals . . . . . . . . . . . . 12 Materials . . . . . . . . : . : 12 Cell Culture Techniques........: : 13 Dibutyltin-Induced He patic Fibrosis : : : 13 Analytical Procedures ........ . . . 14 Hydroxyproline Determination : : : : 14 Preparation of Substrate for Prolyl Hydroxylase Assay . . . . . : . . 15 Prolyl Hydroxylase Assay . . . . . . : 16 In Vitro Collagen Biosynthes is ....... 18 Protein Determination .......... . . 19 Statistical Methods ........... 20 RESULTS . . . . . . . . . . . . . 21

Cell Culture Investigation ........... 21

Liver Hydroxyproline Content ......... 21 


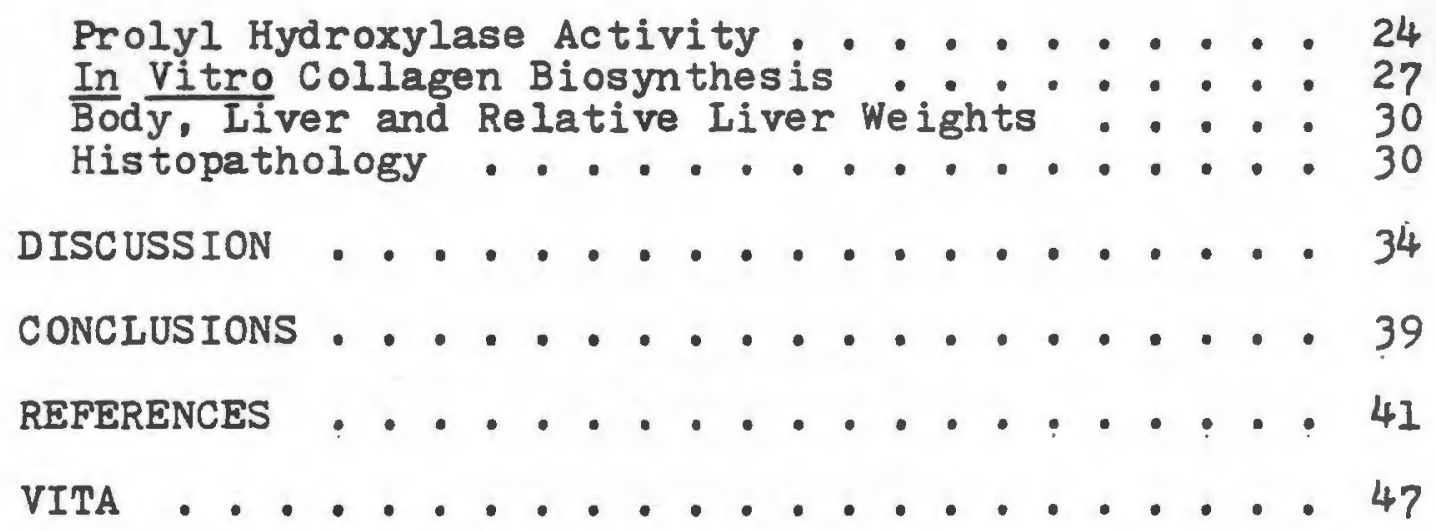




\section{LIST OF TABIES}

Table

Page

I Effect of Dibutyltin on Prolyi Hydroxylase Activity in L929 Cells . . . . . . . . . 22

II Effect of Dibutyltin on Liver Hydroxyproline Content in Rats After 12 Days of Treatment . . 23

III Effect of Dibutyltin on Liver Prolyl Hydrox- . ylase Activity in Rats After 4 Days of Treatment .............. 25

IV Effect of Dibutyltin on Liver Prolyl Hydroxylase Activity in Rats After 12 Days of Treatment ................ 26

$V$ In Vitro Collagen Synthes is in Rat Liver Tissue Minces After 4 Days of Treatment with Dibutyltin . . . . . . . . . . . 28

VI In Vitro Collagen Synthesis. In Rat Liver Tissue Minces After 12 Days of Treatment with Dibutyltin . . . . . . . . . . . . . 29

VII Body, Liver and Relative Liver Weights . . . 32 


\section{LIST OF FIGURES}

Figure

Page

I Effect of Dibutyltin on Rat Body Weight . . 31 


\section{INTRODUCTION}

The toxicity of alkyltin derivatives has been recognized for some time. Intensive investigation of the biological effects of alkyltin compounds began in the mid $1950^{\circ} \mathrm{s}$ in response to increased industrial use of these compounds and a disaster in France caused by the inclusion of an alkyltin derivative in a preparation for the treatment of skin infections. Currently, dialkyltin compounds are widely used as polyvinylchloridestabilizers in medicinally-used plastics, the biological inertness of which has been questioned.

Dialkyltin derivatives produce hepatic and biliary damage (Barnes and Stoner, 1958, Barnes and Magee, 1958, Gaunt et al.. 1968). Barnes and Magee (1958) reported hepatic fibrosis in rats in addition to inflammation and bile duct injury following the administration of dibutyltin dichloride (DBT).

Hepatic fibrosis has long been recognized as one of the sequelae of inflammation and chemically-induced liver damage. This investigation was conducted to determine the fibrogenic potential of DBT in rat liver and the relationship of this fibrogenesis to associated histopathological changes. In vivo and in vitro laboratory models were employed for measurement of hepatic 
collagen synthesis following the oral administration of DBT. 


\section{LITERATURE SURVEY}

\section{Collagen Biosynthesis}

Collagen, the fibrous prote in component of connective tissue, is present in the extracellular matrix as rigid fibers made up of cross-linked collagen molecules. These molecules each consist of three polypeptide chains coiled into a unique left-handed triple helix. Five different types of polypeptide chains, called $\alpha$ chains, have been characterized in four different types of collagen (Crystal, 1974; Miller, 1976). Type I collagen, found primarily in. bone and skin, consists of two $\alpha 1$ chains and one $a 2$ chain, which are distinguishable by their separation on carboxymethylcellulose columns, and is represented as $[\alpha I(I)]_{2}$ 2. The remaining three types of collagen each consist of three identical al chains, with each type of a 1 chain differing slightly in amino acid composition. Type II collagen $\left([\alpha I(I I)]_{3}\right)$ is found primarily in cartilage, type III $\left([a l(I I I)]_{3}\right)$ in fetal tissue, muscle, and aorta, and type IV $\left([\alpha I(I V)]_{3}\right)$ in basement membranes. Collagen biosynthesis consists of the assembly of a proline- and lysine-rich polypeptide precursor of collagen, procollagen, which is subsequently modified by a number of 
post-translational modifications. Hydroxylation of both proline (Prockop and Juva, 1965) and lysine (Sinex et al.. 1959) has been shown to occur subsequent to incorporation of these amino acids into procollagen chains. Following hydroxylation of lysine, some of these residues are glycosylated to galactosylhydroxylysine and glucosylgalactosylhydroxylysine (spiro and spiro, 1971, 1971 a, and $1971^{\mathrm{b}}$ ).

Cellular processing of procollagen a chains also includes interchain disulfide-bond linkage in non-helical regions of the molecule (Bornstein, 1974) which is essential for triple-helix formation (Speakman, 1971). Following the secretion of procollagen, these non-helical regions are removed by the extracellular enzyme, procollagen peptidase (Lapiere et al., 1971, Goldberg et al., 1975). Collagen cross-linking occurs through additional extracellular processing by the enzyme lysyl oxidase which oxidatively deaminates specific lysine residues leaving aldehyde moieties which form cross links through condensation reactions (Siegal et al.. 1970).

\section{Hepatic Fibrosis in Liver Disease}

Collagen is the most abundant protein in the human body and the major protein of connective tissue. Normal liver, however, contains only a small amount of connective tissue. Hepatic fibrosis defines an excess of collagenous 
fibrous tissue in the liver (Leevy et al., 1976). Increased collagen content in human and experimental liver disease leading to cirrhosis has been established by histological observation and chemical determination of hydroxyproline (Kent et al., 1959). Excess collagen accumulation may occur subsequent to the collapse of preformed collagen fibers or from formation of new fibers. However, collapse and aggregation of existing fibrous tissue following hepatocyte necrosis are thought to play a minor role in hepatic fibrosis compared to formation of new fibers (Popper and Ddenfriend, 1970). Increased de novo synthesis of collagen has been associated with the accumulation of collagen in experimental cirrhosis (Huberman et al.. 1969).

An increase in hepatic collagen may result from one or a combination of three processes: increased collagen biosynthesis; increased maturation (cross-linking), fibril formation and deposition of collagen, and decreased catabolism of fibers.

Increased collagen biosynthesis has been demonstrated as increased activity of the intracellular enzyme prolyl hydroxylase in experimental (Takeuchi et al., 1976) and human cirrhosis (Fuller et al., 1976, Fuller et al., 1977). Additional evidence for increased collagen biosynthesis in hepatic fibrosis has been obtained by measurement of 
in vitro incorporation of labeled proline into collagen in human (Chen and Leevy, 1976) and experimental (Rodjkind and Diaz De Leon, 1970) liver biopsies. Increased collagen biosynthesis has also been correlated with an increase in the free proline pool and concomitant decrease in the amount of free glutamic acid, a precursor of proline, in both experimental (Rodjkind and Diaz De Leon, 1970) and human cirrhosis (Kershinobich et al., 1970). Fibroblasts were long thought to be responsible for increased collagen biosynthesis in hepatic fibrosis. Recently, however, enzymes responsible for collagen biosynthesis have been found in many nonfibroblastic cell lines in culture (Langness and Udenfriend, 1974). In the liver, vitamin A-containing perisinusoidal cells (Ito cells or lipocytes) have been implicated in fibrogenesis by serving as resting precursors of fibroblasts (Kent et al., 1976).

Increased extracellular maturation and deposition of collagen may occur in hepatic fibrosis due to the increased availability of surfaces with reduced solid and fluid exchange, which serve as anchors for collagen fibers (Popper and Udenfriend, 1970). Structures which may contain surfaces such as these include the sinusoidal surface of damaged hepatocytes and the basement membranes of proliferated bile ductules and capillaries.

The role of collagen resorption in hepatic fibrosis remains to be established. Extracellular collagenase in 
the liver has been observed by immunohistochemical methods primarily in the liver capsule and portal tracts (Montfort and Perez-Tamayo, 1975); intracellular collagenase in an active form has been reported to be present in Kupffer cells of the hepatic reticuloendothelial system (Fujiwara et al.. 1973). Hepatic collagenase activity has been reported to be increased in carbon tetrachloride-induced experimental fibrosis, primarily in the subacute stage of treatment (Okazaki and Marujama, $1974)$.

Necrosis and inflammation may be primary stimuli of fibrogenesis. The hypothesis that hepatocyte death is fibrogenic has been accepted for some time (Aterman, 1954). Hepatic necrosis has been associated with fibrogenesis in studies with such compounds as carbon tetrachloride (Cameron and Karunaratne, 1936) and dimethylnitrosamine (Madden et al., 1970). Death of hepatocytes has been thought to cause fibrogenesis by release of either macroor micromolecular products from these cells (Popper, 1975). Inflammation has been implicated as a precursor to fibrogenesis. Pharmacologically active compounds formed by inflammatory cells may act as stimuli of fibrogenesis (Popper, 1975). Immune complexes have been suggested as stimuli of fibrogenesis, since localization of such complexes in portal tracts preceded the development of cirrhosis in rats induced by immunization with heterologous sera (Paronetto and Popper, 1966). 
Conversely, necrotic and inflammatory processes often associated with hepatic fibrosis may be initiated by the functional changes resulting from collagen accumulation. Anoxic injury to hepatocytes occurs from pibrosis and the associated circulatory impairment; the resulting breakdown products of dead hepatocytes may in turn be responsible for stimulation of the inflammatory process.

\section{Organotin Toxicity}

Organotin derivatives have demonstrated usefulness as biocidal compounds, heat stabilizers and catalytic agents (Piver, 1973). Dialkyltin compounds are used primarily as heat stabilizers and catalysts in polyvinylchloride and polyurethane production, respectively: trialkyl- and triaryltin derivatives are employed as biocidal agents. Such applications of organotin compounds have resulted in increased industrial use whereby these compounds are now the fourth largest group of organometallics produced.

Dibutyltin derivatives have not been sanctioned by the Food and Drug Administration for use in plastics which come in contact with food, dioctyltin compounds have been developed for this purpose (Piver, 1973). However, dibutyltin derivatives are widely used as polyvinylchloride stabilizers in medicinally-used plastics. 
The biological inertness of plastics used in the medical, dental and pharmaceutical professions has been questioned (Nimni, 1964, Guess and Stetson, 1968, Guess and Haberman, 1968). Organotin-containing polyvinylchloride plastics implanted both intramuscularly and subcutaneously in rats and rabbits causes a local tissue reaction manifested by necrosis, proliferation of granulation tissue and encapsulation by fibrous tissue (Nimni, 1964). Injection of extracts of these plastics and dilutions of up to $1: 10,000$ of dibutyltin dilaurate produced a similar inflammatory response implicating dibutyltin dilaurate as the toxic component. Guess and Haberman (1968) investigated the toxicity of plastics and their additives by cell culture techniques. All ten of the dibutyltin stabilizers studied demonstrated some degree of toxicity.

Extensive investigation of the toxicity of organotin derivatives began in the mid 1950's. The impetus for this was the increased industrial use of these compounds and the "Stalinon" disaster in France in 1954 (Barnes and.Stoner, 1961). "Stalinon" was a preparation sold for the treatment of staphylococcal skin infections, which was said to contain $15 \mathrm{mg}$ diethyltin diiodide and $100 \mathrm{mg}$ linoleic acid per capsule, but later was found to contain large quantities of mono- and triethyltin. The 
recommended dose was six capsules per day for eight days. Two hundred and seventeen poisonings resulting in 100 deaths were reported due to "Stalinon". Symptoms included persistent headache, vertigo, visual and psychic disturbances, vomiting and abdominal pain. Autopsy revealed interstitial cerebral edema and some venous endothelial proliferation with thrombosis and hemorrhages.

Investigation of a series of alkyltin derivatives revealed that, with few exceptions, the toxicity of these compounds increases as the size of the alkyl group decreases and that trialkyl derivatives exhibit greater toxicity than their dialkyl counterparts (Stoner et al.. 1955).

Trialkyltin compounds have been shown to produce interstitial edema of the white matter of the brain in rats (Magee et al., 1957) and inhibit oxidative phosphorylation in vitro (Aldridge and Cremer, 1955, Aldridge and Street, 1964, 1970, and 1971). Inhibition of muscular contractility in vitro associated with disruption of mitochondria, disorganization of muscle fibers and depletion of neuromicrotubules has also been observed (Tan and Ng. 1977).

Dialkyltin differ from trialkyltin compounds in that the primary lesion of these compounds is biliary and hepatic damage (Barnes and Stoner, 1958, Barnes and Magee, 1958, Gaunt et al., 1968). Dibutyltin is the most active 
of the dialkyltin series in this respect. Barnes and Magee (1958) reported bile duct damage and liver inflammation two days after oral administration of dibutyltin dichloride ( $50 \mathrm{mg} / \mathrm{kg}$ for three days). After six months, the bile duct was shortened and thickened and hepatic portal fibrosis was evident. 


\section{EXPERIMENTAL}

\section{Animals}

Male Long Evans rats weighing 250-350 grams were purchased Prom Charles River Breeding Laboratories, Inc. (Wilmington, MA). The rats were housed in groups of six in colony cages at an ambient temperature of $24-27^{\circ} \mathrm{C}$. with alternating 12 hour light/dark cycles. Rats were fed Purina Laboratory Chow and water ad libitium.

\section{Materials}

Di-n-butyltin dichloride was purchased from Eastman Kodak Co. (Rochester, NY). The radioactive amino acids, 4- ${ }^{3} \mathrm{H}$-proline (specific activity $25-30 \mathrm{ci} / m m o l e$ ) and $2,3-3 \mathrm{H}$-proline (specific activity $20 \mathrm{ci} /$ mmole) were purchased from New England Nuclear Corporation (Boston, MA). Bacterial collagenase, free of nonspecific proteases, was purchased from Advanced Biofactures (Lymbrook, NY). Eagles Minimum Essential Medium was obtained from Grand Island Biological Company (Grand Island, NY). Analytical grade reagents were used throughout the investigation. 


\section{Cell Culture Technigues}

An established line of 1929 fibroblast cells were maintained in monolayer cultures in Eagles Minimum Essential Medium with $10 \%$ fetal calf serum and chlortetracycline $(50 \mathrm{ug} / \mathrm{ml})$. Treated cell cultures were incubated with dibutyltin dichloride $(0.1 \mathrm{mg} / \mathrm{ml}$ in $25 \%$ ethanol) during late $\log$ phase at final concentrations of $3 \times 10^{-7} \mathrm{M}$ and $3 \times 10^{-6} \mathrm{M}$. Control cultures received equivalent amounts of $25 \%$ ethanol. After 24 hours, medium was decanted and cells harvested by centrifugation following the addition of $0.1 \%$ trypsin. The pellet was washed three times with phosphate buffered saline and disrupted by ultrasonic energy ( 30 watts for two 15 second periods) in $1 \mathrm{ml}$ $0.25 \mathrm{M}$ sucrose. Prolyl hydroxylase activity was determined in 50 and 100 ul aliquots of cell sonicates.

\section{Dibutyltin-Induced Hepatic Fibrosis}

Fibrosis and associated liver injury was produced in male Iong Evans rats by the administration of dibutyltin dichloride in corn oil by oral intubation. Dibutyltin dichloride was administered daily in animals treated for four days and every two days in animals treated for 12 days. Rats were sacrificed by decapitation 24 hours after the last administration of dibutyltin dichloride. The 
livers were removed and quickly chilled. Sections of liver tissue were fixed and prepared for light microscopy using hematoxylin-eosin and trichrome stains. Liver samples were also prepared for determination of prolyl hydroxylase activity and in vitro collagen synthesis. Remaining liver tissue was stored frozen for determination of hydroxyproline content.

\section{Hydroxyproline Determination}

Liver hydroxyproline content was determined using the method of Kivirikko et al. (1967) with some modifications. Acid hydrolyzates of liver were prepared by autoclaving $150 \mathrm{mg}$ liver in $4 \mathrm{mls} 6 \mathrm{~N} \mathrm{HCl}$ for 24 hours. Following hydrolysis, samples were decolorized with activated charcoal, centrifuged at low speed (1000 rpm) and the resultant supernates filtered. Using phenolphthale in as an indicator, samples were adjusted to a pink color with 1 and $10 \mathrm{~N}$ potassium hydroxide. Aliquots containing 3-15 ug hydroxyproline and hydroxyproline standards (5$25 \mathrm{ug})$ were diluted to $4 \mathrm{mls}$. The $\mathrm{pH}$ was again adjusted using phenolphthalein as an indicator and solutions were saturated with potassium chloride. One ml potassium borate buffer ( $\mathrm{pH} 8.7$ ) and $0.5 \mathrm{ml} 10 \%$ alanine were added with mixing. After 30 minutes samples were oxidized with $1 \mathrm{ml} 0.2 \mathrm{M}$ chloramine-T solution at room temperature. 
The reaction was stopped after 25 minutes with 3 mls 3.6 M sodium thiosulfate. Toluene-soluble oxidation products were extracted in $5 \mathrm{mls}$ toluene and discarded. Pyrrole was formed from oxidation products of hydroxyproline remaining in solution by heating to $100^{\circ} \mathrm{C}$ for 30 minutes. After cooling. pyrrole was extracted with $5 \mathrm{mls}$ toluene. The addition of $1 \mathrm{ml}$ Ehrlich's reagent (p-dime thylaminobenzaldehyde) to $2.5 \mathrm{mls}$ extract produced a pyrrole chromophore after 30 minutes at room temperature with a characteristic absorbance at $560 \mathrm{mu}$.

\section{Preparation of Substrate for Prolyl Hydroxylase Assay}

The tritium labeled substrate was prepared by the method of futton et al. (1966) with some modifications. Twenty-five to thirty dozen, 7-day-old decapitated chick embryos were placed in ice-cold Krebs-Ringer buffer ${ }^{2}$ (Stone and Meister, 1962). After washing twice with ice-cold Krebs, embryos were minced in the presence of a small amount of ice-cold Krebs. Five to six gram portions of minced embryo were placed in $50 \mathrm{ml}$ beakers and enough Krebs buffer was added to bring the final volume to $20 \mathrm{mls}$. Following the addition of $1.0 \mathrm{mci}$

$\mathrm{a}_{\mathrm{NaCl}}, 1.285 \mathrm{~g} ; \mathrm{KCI}, 0.224 \mathrm{~g}, \mathrm{MgSO}_{4}, 0.144, \mathrm{CaCl}_{2}$, $0.144 \mathrm{~g}: \mathrm{KH}_{2} \mathrm{PO}_{4}: 0.544$ gi $\mathrm{NaHCO}_{3}, 2.10 \mathrm{~g}: \mathrm{D}-\mathrm{Glucose}$, $1.80 \mathrm{~g} /$ and $^{2}$ distilled water to 1 liter. 
4- ${ }^{3} \mathrm{H}$-proline and $20 \mathrm{ul}$ of $1.0 \mathrm{M} \alpha, \alpha$-dipyridyl, the mixture was incubated for two hours at $37^{\circ} \mathrm{C}$ under $\mathrm{O}_{2}-\mathrm{CO}_{2}$ $(95 / 5 \%)$ in a metabolic shaker. After two hours, the embryo minces were centrifuged at $30,000 \mathrm{rpm}$ for 90 minutes and the supernates discarded. Newly synthesized collagen was extracted from the pellet with $0.5 \mathrm{M}$ acetic acid ( $2 \mathrm{ml} / \mathrm{gm}$ tissue) overnight. After centrifugation for 90 minutes at $30,000 \mathrm{rpm}$, the supernate containing newly-formed, unhydroxylated collagen was dialyzed against ten volumes of $0.01 \mathrm{M}$ Tris HCl buffer ( $\mathrm{pH}$ ?.4) with at least four changes. The substrate was then autoclaved for 15 minutes and redialyzed against three changes of 10 volumes of Tris HCl buffer ( $\mathrm{pH} 7.4)$. Substrate was then calibrated for specific activity and linearity with a standard purified rabbit enzyme (Chichester et al.. 1976) and frozen in $10 \mathrm{ml}$ aliquots.

\section{Prolyl Hydroxylase Activity}

Immediately after rats were sacrificed, livers were removed and $15-25 \mathrm{mg}$ aliquots of tissue were homogenized in $300 \mathrm{ul}$ of buffer containing $0.25 \mathrm{M}$ sucrose, $10^{-5} \mathrm{M}$ ethylenediaminetetraacetic acid, $10^{-5} \mathrm{M}$ dithiothreitol and $0.01 \%$ Triton. Prolyl hydroxylase activity in 50 and $100 \mathrm{ul}$ aliquots of homogenate was determined by the method 
of Hutton et al. (1966) with some modifications. Aliquots of liver homogenates were incubated at $30^{\circ} \mathrm{C}$ for $30 \mathrm{~min}-$ utes in a mixture containing approximately $600,000 \mathrm{cpm}$ (depending on substrate batch) of tritiated substrate $(0.2 \mathrm{ml}), 0.5 \mathrm{mM}$ ascorbate, $0.1 \mathrm{mM} \alpha$-ketoglutarate, $0.1 \mathrm{mM}$ ferrous ammonium sulfate, $0.05 \mathrm{M}$ Tris HCl buffer $(\mathrm{pH} 7.4), 0.2 \%$ bovine serum albumin and $0.02 \%$ catalase. The prolyl hydroxylase reaction was stopped after 30 minutes by the addition of 0.1 volume $50 \%$ trichloroacetic acid. Tritiated water was then collected by vacuum distillation, a measured fraction of tritiated water was counted for radioactivity in a Packard Tri-Carb Liquid Scintillation Spectrometer (Model 3310). This radioactivity reflects the stoichiometric formation of hydroxyproline and tritiated water by prolyl hydroxylase in the presence of cofactors and labeled substrate as described above (Rhoads and Udenfriend, 1970). Due to variability in substrate batches, a conversion factor, derived from substrate calibration with standard enzyme, is employed to permit comparisons of prolyl hydroxylase activity values when different substrate preparations are used. 


\section{In Vitro Collagen Biosynthesis}

Collagen and noncollagen prote in synthesis by liver tissue in vitro was determined by the method of Diegelmann et al. (1975) with modifications. Approximately $100 \mathrm{mg}$ of freshly dissected liver minces were incubated for 24 hours at $37^{\circ} \mathrm{C}$ under $\mathrm{O}_{2}-\mathrm{CO}_{2}(95 / 5 \%)$ in $4 \mathrm{mls}$ of Eagles minimum essential medium containing $4-{ }^{3} \mathrm{H}-$ or $2,3-3^{3}$-proline $(50$ uci/ml), $10^{-4} \mathrm{M}$ ascorbate and $50 \mathrm{ug} / \mathrm{ml} \quad \beta$-aminoproprionitrile. Experiments have been conducted confirming that label incorporation into collagen and noncollagen prote in is linear against time between 6 and 24 hours, the percent label in collagen does not change during this 24 hours. The incubation mixture was homogenized in a Bellco glass/ glass homogenizer and protein was precipitated by the addition of 0.1 volume $50 \%$ trichloroacetic acid at $4^{\circ} \mathrm{C}$. The pellet, collected by centrifugation at $5,000 \mathrm{rpm}$ for 30. minutes, was resuspended in $0.5 \mathrm{M}$ acetic acid and dialyzed against 100 volumes of $0.5 \mathrm{M}$ acetic acid with two changes and against 100 volumes of $0.05 \mathrm{M}$ Tris $\mathrm{HCl}$ buffer ( $\mathrm{pH} 7.4$ ) with two changes to remove unincorporated labeled proline. Tubes of $0.4 \mathrm{ml}$ aliquots of sample were then incubated for 18 hours at $37^{\circ} \mathrm{C}$ in a mixture containing $0.05 \mathrm{M}$ Tris HCl buffer ( $\mathrm{pH}$ 7.4), N-ethylmaleimide (2.5 umole), calcium chloride ( 0.5 umole), $0.1 \mathrm{ml}$ chloroform and 130 units of bacterial collagenase. Duplicate tubes were incubated without collagenase, which served as enzyme blanks. 
Following incubation, the reaction was stopped and protein was coprecipitated with 0.1 volume bovine serum albumin $(1.0 \%)$ by the addition of one volume $10 \%$ trichloroacetic acid. After 30 minutes on ice, samples were centrifuged at $5.000 \mathrm{rpm}$ for 30 minutes. The pellet was digested in $2 \mathrm{mls}$ Digestol ${ }^{R}$ (Yorktown, Hackensack, $\mathrm{NJ}$ ) and counted in $10 \mathrm{mls}$ toluene-based scintillation cocktail. The 5\% trichloroacetic acid supernate was again coprecipitated using bovine serum albumin $(1.0 \%)$ and counted in $10 \mathrm{mls}$ Hydromix $x^{R}$ (Yorktown, Hackensack, NJ). Protein content was determined on liver homogenates. Collagen and noncollagen protein synthesis per unit protein was calculated from collagenasedigested protein in the supernate and collagenase-resistant protein in the pellet, respectively. Relative collagen synthesis was calculated using a formula which accounted for the relative enrichment of collagen proline/hydroxyproline content ( 5.4 times) compared to noncollagen protein (Diegelmann et al., 1975).

\section{Prote in Determination}

Protein content was determined by the method of Lowry et al. (1951) using bovine serum albumin as the protein standard. The intensity of the characteristic blue color was read at $750 \mathrm{mu}$ on a Gilford Model 250 Spectrophotometer. 


\section{Statistical Methods}

Students' t-test was used to test for significant differences between sample means. The sample means, standard errors of the means and t-statistics were calculated on an Olivetti-Underwood Programma 101 computer using the following formulae.

a.) Arithmetic means of sample:

$$
\bar{x}_{1}=\frac{\Sigma x_{1}}{N_{1}}, \bar{x}_{2}=\frac{\Sigma x_{2}}{N_{2}}
$$

b.) Estimated standard error of the means

$$
\hat{\sigma}_{\bar{x}_{1}}=\frac{s_{1}}{\sqrt{N_{1}-1}}, \hat{\sigma}_{\bar{x}_{2}}=\frac{s_{2}}{\sqrt{N_{2}-1}}
$$

c.) t-statistic:

$$
t=\frac{\left|\bar{x}_{1}-\bar{x}_{2}\right|}{\hat{\sigma}_{\bar{x}_{1}}-\bar{x}_{2}}
$$

Acceptable level of significance in these studies was defined as $P<0.05$ for a one-tailed t-test. 


\section{RESULTS}

\section{Cell culture Investigation}

The effect of dibutyltin dichloride (DBT) on mouse fibroblasts in cell culture is shown in Table 1 . When L929 fibroblasts were incubated with DBT at concentrations of $3 \times 10^{-7} \mathrm{M}$ and $3 \times 10^{-6} \mathrm{M}$ at late $\log$ phase, no change in prolyl hydroxylase activity in cell sonicates was observed compared to control values.

\section{Liver Hydroxyproline Content}

Since hydroxyproline does not appear in significant amounts in noncollagen protein, the amount of this amino acid reflects the amount of collagen present in liver tissue. The effect of DBT on liver hydroxyproline content in rats following treatment every two days for 12 days is shown in Table II. The amount of hydroxyproline, expressed as ug/mg liver wet weight, reflects measurement of the pyrrole chromophore of this amino acid in liver acid hydrolyzates. In the $10 \mathrm{mg} / \mathrm{kg}$-treatment group, there was no change in liver hydroxyproline content. 
Effect of Dibutyltin (DBT) on Prolyl Hydroxylase Activity in L - 929 Cells

Group $\quad$ prolyl hydroxylase activity

$\mathrm{cpm} / \mathrm{ug}$ protein

Control

54

60

$\operatorname{DBT}\left(3 \times 10^{-7} \mathrm{M}\right)$

56

60

$\operatorname{DBT}\left(3 \times 10^{-6} \mathrm{M}\right)$

47

64

${ }^{\text {a }}$ late $10 \mathrm{~g}$ phase L-929 cells were incubated with DBT for 12 hours.

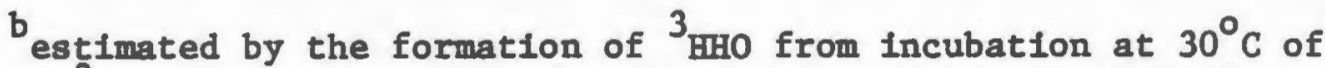
4-3 H-proline rich substrate and cofactors with 50 and 100 ul aliquots of cell sonicates prepared as: described in the methods. Each value represents mean of enzyme activity measurements from one flask of cells reported as cpm/ug protein/30 min. 
TABLE II

Effect of Dibutyltin (DBT) on Liver Hydroxyproline Content in Rats After 12 Days of Treatment

\begin{tabular}{lcc}
\hline Group & $\mathrm{N}^{\mathrm{b}}$ & $\begin{array}{c}\text { Hydroxyproline } \\
\text { ug/mg } 1 \text { liver wet weight }\end{array}$ \\
\hline Control & 6 & $\begin{array}{c}0.125 \pm 0.004 \\
(\text { range } 0.105-0.133)\end{array}$ \\
DBT (10 mg/kg) & 7 & $\begin{array}{c}0.148 \pm 0.019 \\
(\text { range } 0.102-0.249)\end{array}$ \\
DBT $(20 \mathrm{mg} / \mathrm{kg})$ & 6 & $\begin{array}{c}0.266 \pm 0.044^{\mathrm{d}} \\
(\text { range } 0.157-0.447)\end{array}$ \\
\hline
\end{tabular}

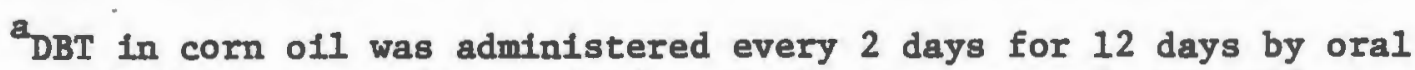
intubation; controls recelved equivalent amounts of corn o1l.

$b_{N}$ represents the number of rats in each group.

c determinated colorimetrically in 1 iver acid hydrolyzates as described in the methods.

Values are mean \pm S.E.M.

$d_{P}<0.005$ vs. control. 
However, DBT administration at the higher dose of 20 $\mathrm{mg} / \mathrm{kg}$ produced a greater than two-fold increase $(\mathrm{p}<0.005)$ in the amount of hydroxyproline.

\section{Prolyl Hydroxylase Activity}

Since prolyl residues are not hydroxylated before they are in peptide-bound form and hydroxyproline does not occur to any significant extent in noncollagen protein, proline hydroxylation can be used as a measure of collagen synthesis in rat liver tissue. The effect of DBT on prolyl hydroxylase activity in rat liver homogenates after 4 and 12 days of treatment is seen in Tables III and IV, respectively. After four days of DBT treatment, prolyl hydroxylase activity increased approximately $50 \%(p<0.01)$ in the $10 \mathrm{mg} / \mathrm{kg}$ group and about $130 \%(p<0.01)$ in the $20 \mathrm{mg} / \mathrm{kg}$ group. Animals receiving the same doses of DBT every two days for 12 days (Table IV) showed a relatively modest increase in prolyl hydroxylase activity. There was no change in prolyl hydroxylase activity in the $10 \mathrm{mg} / \mathrm{kg}$ group and an increase of approximately $50 \%(p<0.05)$ in the 20 $\mathrm{mg} / \mathrm{kg}$ group. 
TABLE III

Effect of Dibutyltin (DBT) on Liver Prolyl Hydroxylase (PH) Activity in Rats After 4 Days of Treatment

\begin{tabular}{lcc}
\hline Group & $\mathrm{N}^{\mathrm{b}}$ & $\begin{array}{c}\text { PH activity } \\
\text { cpm/mg protein }\end{array}$ \\
\hline Contro1 & 5 & $\begin{array}{c}1129 \pm 94 \\
(\text { range } 85 \overline{7}-1297)\end{array}$ \\
DBT $(10 \mathrm{mg} / \mathrm{kg})$ & 5 & $\begin{array}{c}1760 \pm 169 \mathrm{~d} \\
(\text { range } 1326-2226)\end{array}$ \\
DBT $(20 \mathrm{mg} / \mathrm{kg})$ & 5 & $\begin{array}{c}2537 \pm 258^{\mathrm{d}} \\
(\text { range } 1709-3095)\end{array}$ \\
\hline
\end{tabular}

aDT in corn oil was administered daily for 4 days by oral intubation; controls received equivalent amounts of corn oil.

${ }^{b} \mathbf{N}$ represents the number of rats in each group.

cestimated by the formation of ${ }^{3}$ HHO from incubation at $30^{\circ} \mathrm{C}$ of 4-3 $\mathrm{B}$-proline-rich substrate and cofactors with 50 and 100 uI aliquots of liver homogenates prepared as described in the methods and reported as cpm $3 \mathrm{HHO} / \mathrm{mg}$ protein/30 min.

Values are mean \pm S.E.M.

$\mathrm{d}_{\mathbf{P}}<0.01$ vs. control. 
TABLE IV

Effect of Dibutyltin (DBT) on Liver Prolyl Hydroxylase (PH) Activity in Rats After 12 Days of Treatment

\begin{tabular}{lcc}
\hline Group & $\mathrm{N}^{\mathrm{b}}$ & $\begin{array}{c}\text { PH activityc } \\
\text { cpm/mg protein }\end{array}$ \\
\hline Control & 12 & $2030 \pm 202$ \\
& & $($ range $1290-3446)$ \\
DBT $(10 \mathrm{mg} / \mathrm{kg})$ & 15 & $1873 \pm 95$ \\
& 12 & $($ range $1310-2517)$ \\
DBT $(20 \mathrm{mg} / \mathrm{kg})$ & $1379 \pm 400$ \\
& & $(\text { range } 1974-6527)^{\mathrm{d}}$ \\
\hline
\end{tabular}

aDBT in corn oil was administered every 2 days for 12 days by oral intubation; controls recelved equivalent amounts of corn oil.

$b_{N}$ represents the number of rats in each group.

$c_{\text {estimated by the formation of }}^{3} \mathrm{HHO}$ from incubation at $30^{\circ} \mathrm{C}$ of

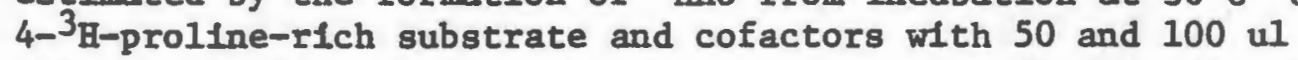
aliquots of liver homogenates prepared as described in the methods and reported as cpm $\mathrm{HHO} / \mathrm{mg}$ protein/30 min.

Values are mean \pm S.E.M.

$\mathrm{d}_{\mathbf{P}}<0.05$ vs. control. 


\section{In Vitro Collagen Synthesis}

Although prolyI hydroxylase activity is a sensitive indicator of increased fibrogenes is in liver homogenates. it has not been shown to be a rate-limiting step in collagen biosynthesis. A more direct indication of absolute and relative collagen synthesis is obtained by measurement of in vitro incorporation of ${ }^{3} \mathrm{H}$-proline into collagenase-degradable and collagenase-resistant protein. The effect of DBT on in vitro collagen synthesis in rat liver tissue minces after 4 and 12 days of treatment is shown in Tables $V$ and VI, respectively. After 4 days of DBT treatment at a dose of $20 \mathrm{mg} / \mathrm{kg}$, the in vitro incorporation of labeled proline into collagenase-digestible protein increased approximately five-fold ( $p<0.001)$. There was a concomitant increase in the amount of label incorporated into collagenase-resistant protein of approximately the same magnitude. As a result, no significant change was observed in the percent of labeled protein digested by collagenase. DBT treatment every two days for 12 days (Table VI) at doses of 10 and $20 \mathrm{mg} / \mathrm{kg}$ produced a significant increase in the percent of collagenase-digestible protein at the higher dose only $(p<0.05)$. This increase reflects increased incorporation of labeled proline into collagenase-digestible protein relative to decreased incorporation into collagenase-resistant protein. 


\section{TABLE V}

In Vitro Collagen Synthesis in Rat Liver Tissue Minces After 4 Days of Treatment With Dibutyltin (DBT) ${ }^{a}$

\begin{tabular}{|c|c|c|c|c|}
\hline Group & $N^{b}$ & $\begin{array}{l}2,3^{3} \text { H-proline } \\
\text { released from } \\
\text { liver protein by } \\
\text { collagenase } \\
(\text { cpm/mg protein) }\end{array}$ & $\begin{array}{l}2,3^{3} \text { H-proline } \\
\text { incorporated Into } \\
\text { collagenase-resistant } \\
\text { protein } \\
(\mathrm{cpm} / \mathrm{mg} \text { protein) }\end{array}$ & $\begin{array}{l}\text { z of total } \\
\text { labeled protein } \\
\text { digested by } \\
\text { collagenase }\end{array}$ \\
\hline Contro1 & 4 & $644 \pm 226$ & $283,750 \pm 164,840$ & $0.098 \pm 0.042$ \\
\hline $\begin{array}{l}\text { DBT } \\
(20 \mathrm{mg} / \mathrm{kg})\end{array}$ & 7 & $3,098 \pm 367^{d}$ & $1,606,840 \pm 185,080^{d}$ & $0.039 \pm 0.006$ \\
\hline
\end{tabular}

$a_{D B T}$ in corn ofl was administered dafly for 4 days by oral intubation; controls recelved equivalent amounts of corn oll.

$b_{N}$ represents the number of rats in each group.

${ }^{c}$ Collagenase digestion performed on proteln obtained by precipitation with $5 \%$ trichloroacetic acid following 24 hour incubation with labeled proline as described in the methods. Values are mean $t$ S.E.M.

$d_{p}<0.001$ vs. control. 
TABLE VI

In Vitro Collagen Synthesis in Rat Liver Tissue Minces After 12 Days of Treatment With Dibutyltin (DBT) ${ }^{a}$

\begin{tabular}{|c|c|c|c|c|}
\hline GROUP & $\mathrm{N}^{\mathrm{b}}$ & $\begin{array}{l}4^{3} \text { H-proline released } \\
\text { from liver proteln } \\
\text { by collagenase } \\
(\mathrm{cpm} / \mathrm{mg} \text { proteln) }\end{array}$ & $\begin{array}{l}4^{3} \text { H-proline Incorporated } \\
\text { Into collagenase-resistant } \\
\text { protein } \\
(\mathrm{cpm} / \mathrm{mg} \text { protein)c }\end{array}$ & $\begin{array}{l}\text { \% of total } \\
\text { labeled protein } \\
\text { digested by } \\
\text { collagenase }\end{array}$ \\
\hline CONTROL & 6 & $307 \pm 81$ & $19,200 \pm 3,000$ & $0.300 \pm 0.081$ \\
\hline $\begin{array}{l}\text { DBT } \\
(10 \mathrm{mg} / \mathrm{kg})\end{array}$ & 7 & $157 \pm 61$ & $11,900 \pm 500^{d}$ & $0.282 \pm 0.100$ \\
\hline $\begin{array}{l}\text { DBT } \\
(20 \mathrm{mg} / \mathrm{kg})\end{array}$ & 5 & $440 \pm 75$ & $13,400 \pm 900^{d}$ & $0.590 \pm 0.082^{d}$ \\
\hline
\end{tabular}

${ }^{a}$ DBT in corn ofl was administered every 2 days for 12 days by oral intubation; controls recelved equivalent amounts of corn oil.

${ }^{b}$ represents the number of rats in each group.

${ }^{c}$ Collagenase digestion performed on protein obtalned by precipltation with $5 \%$ trichloroacetic acid following 24 hour incubation with labeled proline as described in the methods.

$d_{P}<0.05$ vs. control. 


\section{Body, Liver and Relative Liver Weights}

The effect of four days of DBT treatment $(20 \mathrm{mg} / \mathrm{kg})$ on weight gain is shown in Figure $I$. Dibutyltin-treated rats lost approximately eight grams per day resulting in a mean body weight which was $26 \%$ less $(p<0.001)$ than control animals. After DBT treatment every two days for 12 days, the mean body weight was $12 \%$ less $(p<0.05)$ than control rats (Table VII).

\section{Histopathology}

Dibutyltin treatment at a dose of $20 \mathrm{mg} / \mathrm{kg}$ for four days produced inflammatory and biliary tract changes in rats. Inflammatory cells were observed throughout the portal tracts, most notably in and around bile ducts. Proliferation of bile ducts was evident at this time. At a dose of $10 \mathrm{mg} / \mathrm{kg}$ for four days, inflammation and biliary damage was minimal.

After 12 days of DBT-treatment $(20 \mathrm{mg} / \mathrm{kg})$, inflammation and biliary damage was extensive. Both mononuclear and polymorphonuclear cells were present in and around portal tracts and extending out into parenchyma leaving only central vein areas preserved. Bile ducts were proliferated and congested with polymorphonuclear cells: damage to the bile duct epithelial cells was 
FIGURE I

Effect of Dibutyltin on Rat Body Weight ${ }^{2}$

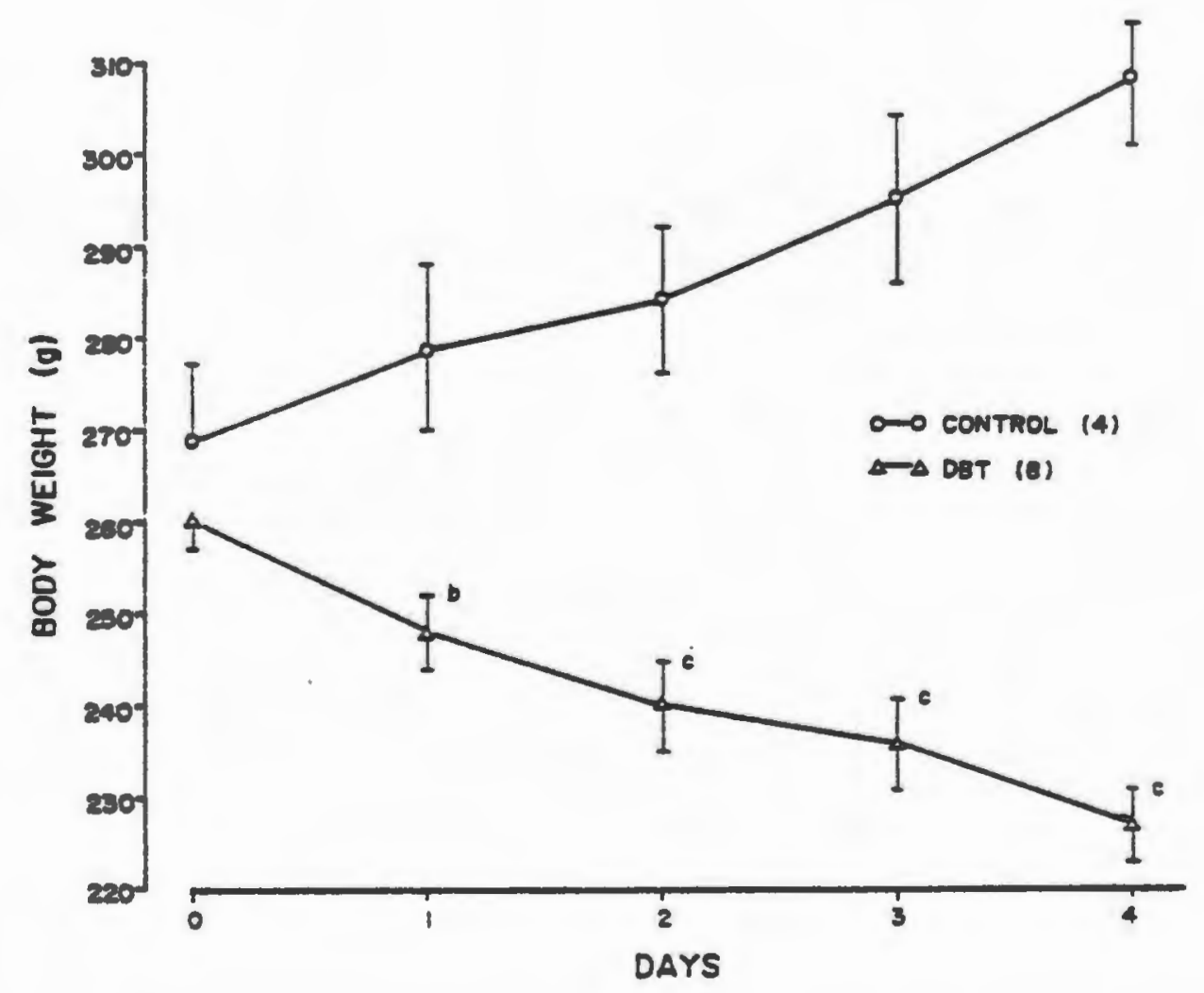

aibutyltin in corn oil $(20 \mathrm{mg} / \mathrm{kg}$ ) was administered every day for 4 days by oral intubation, controls received equivalent amounts of corn oil. Values are mean - S.E.M.

${ }^{b} P<0.01$ vs. control

$c_{P}<0.001$ vs. control 
TABLE VII Effect of Dibutyltin on Body, Liver and
Relative Liver Weights

\begin{tabular}{|c|c|c|c|c|}
\hline Group & N & $\begin{array}{l}\text { Body } \\
\text { We1ght } \\
(g)\end{array}$ & $\begin{array}{l}\text { Body } \\
\text { Welght } \\
(g)\end{array}$ & $\begin{array}{l}\text { Relative } \\
\text { Liver Welght } \\
\text { (g liver/100g body } \\
\text { weight) }\end{array}$ \\
\hline Control & 6 & $384 \pm 14$ & $12.85 \pm 0.94$ & $3.33 \pm 0.15$ \\
\hline $\begin{array}{l}\text { DBT } \\
\left(10 \mathrm{mg} / \mathrm{Kg}_{\mathrm{g}}\right)\end{array}$ & 7 & $382 \pm 6$ & $13.01 \pm 0.60$ & $3.40 \pm 0.12$ \\
\hline $\begin{array}{l}\text { DBT } \\
(20 \mathrm{mg} / \mathrm{Kg})\end{array}$ & 6 & $339 \pm 14^{b}$ & $13.22 \pm 0.70$ & $3.91 \pm 0.23$ \\
\hline
\end{tabular}

aBT in corn oll was administered every 2 days for 12 days by oral Intubation; controls recelved equivalent amounts of corn o1l.

$b_{P}<0.05$ vs. control. 
appreciable. Areas of necrosis, both focal and confluent, were seen at this time. Large infarcted areas and nonspecific granulomatous lesions were present throughout the parenchyma. Finally, both periportal and parenchymal accumulation of fibrous tissue was demonstrated by trichrome stain. Treatment with $10 \mathrm{mg} / \mathrm{kg}$ DBT for 12 days produced moderate inflammation and biliary damage. with minimal fibrosis and necrosis. 


\section{DISCUSSION}

Biochemical and histological studies of DBT-treated rat livers after 12 days of treatment reveals increased accumulation of collagen which is associated with numerous histopathological changes. Histological observation of fibrous tissue and the greater than two-fold increase in hydroxyproline content following $20 \mathrm{mg} / \mathrm{kg}$ DBT treatment indicates the development of hepatic fibrosis which has not progressed to cirrhosis. There is no increase in hydroxyproline in the $10 \mathrm{mg} / \mathrm{kg}$ group and minimal histological evidence of fibrous tissue. The correlation between histologically demonstrable fibrous tissue and biochemically determined collagen is in agreement with that seen in dietary (Brunner et al.. 1973) and carbon tetrachloride-induced cirrhosis (Rojkind, 1973).

Blochemical data indicate only a moderate increase in hepatic collagen synthesis at 12 days when extensive fibrosis and necrosis are already established by histopathological criteria. The activity of prolyl hydroxylase is increased only $50 \%$ over controls, and there is no elevation in the amount of collagenase-digestible protein synthesized in vitro in liver biopsies. 
The increased collagen accumulation at 12 days can, however, be attributed to an increase in relative, or percent, total protein synthesis directed toward collagen synthesis as a result of a significant decrease in the synthesis of noncollagen protein. The percent collagen synthesis in vitro is a comparison of collagen and noncollagen synthesis per unit of protein. Histological observation suggests a decrease in viable areas of parenchyma and an increase in necrotic and fibrous tissue. This in turn would suggest a decrease in noncollagenproducing cells with a resultant increase in collagen production per unit of protein. The two-fold increase in percent collagen synthesized in vitro shown in DBTtreated livers after 12 days supports this conclusion.

Since significant liver hydroxyproline accumulation is evident after 12 days of DBT treatment, the effect of DBT ( 10 and $20 \mathrm{mg} / \mathrm{kg}$ ) on collagen synthesis in rat liver is investigated after only four days of treatment. Although histological observation of liver biopsies with a collagen specific stain fails to show evidence of fibrosis at four days, biochemical studies demonstrate an increase in collagen synthes is.

Prolyl hydroxylase activity in liver homogenates is increased greater than $50 \%$ and $130 \%$ in the 10 and $20 \mathrm{mg} / \mathrm{kg}$ 
DBT-treated rats, respectively. Increased activity of this enzyme has been shown to precede the increase in hydroxyproline content in carbon tetrachloride-induced cirrhosis (Takeuchi et al.. 1967) and histological evidence of advanced cirrhosis in human liver biopsies (Fuller et al., 1976; Fuller et al., 1977). The observed increase of prolyl hydroxylase activity in DBT-treated rat livers, therefore, suggests that fibrogenesis is increased at four days, prior to observable collagen accumulation.

Additional evidence for increased collagen synthesis after four days of DBT treatment is seen in the six-fold increase in in vitro synthesis of collagenase-digestible protein. There is no apparent enrichment in the amount of protein synthesis directed to collagen because of a concomitant increase in noncollagen prote in synthesis. However, this increase in noncollagen prote in synthesis may represent the protein made by inflammatory cells detected by light microscopy.

The effect of DBT on fibroblasts is determined using monolayer cell cultures of L929 fibroblasts. Prolyl hydroxylase activity is used as a measure of collagen synthesis in these cells. A direct correlation between the activity of this enzyme and the formation of hydroxylated collagen has been reported by Gribble et al. (1969) 
in cell cultures of 1929 fibroblasts. That incubation with DBT had no effect on the activity of prolyl hydroxylase in I929 cells suggests that this compound does not directly stimulate collagen synthesis by fibroblasts in vivo and that the mechanism of DBT-induced hepatic fibrogenesis requires a step intermediate to the direct stimulation of collagen-producing cells.

The increased fibrogenesis seen after four days of DBT treatment appears to be a sequela of inflammation and/or bile duct injury and proliferation, the only histopathological changes observed at this time.

Diethyltin dichloride has been shown to decrease oxygen uptake in rat brain in vitro by binding to sulfhydral groups in $\alpha$-keto acid oxidases with the resultant inhibition of these enzymes (Aldridge and Cremer, 1955). Since the presence of DBT has been demonstrated in the bile (Barnes and Magee, 1958), and dialkyltin compounds have many biological properties in common (Stoner et al.. 1954; Barnes and Stoner, 1961), DBT may produce its biliary damage by decreasing oxygen uptake, thereby producing anoxia in bile duct epithelial cells. Further support for inflammation in portal tracts and bile duct damage being the primary lesion of DBT is presented by the histological picture after 12 days of treatment where the hepatocyte injury observed is 
primarily peripheral. At this time, liver injury resembles that of drug-induced hepatitis with necrosis and fibrosis (Leevy et al., 1976) with the exception of preserved centrilobular parenchyma. 
CONCLUSIONS

(1) After four days of DBT treatment $(20 \mathrm{mg} / \mathrm{kg})$. histological observation of rat livers showed inflammation in portal tracts and bile duct inflammation and proliferation. Prolyl hydroxylase activity was increased 50 and $130 \%$ over control values in the 10 and $20 \mathrm{mg} / \mathrm{kg}$ groups, respectively. The amount of in vitro collagen synthesis was increased five-fold in the higher dose group. There was, however, no change in percent collagen synthesis since noncollagen protein synthesis was also elevated five-fold, probably as a result of inflammatory cell prote in synthesis. The data obtained indicate increased fibrogenesis at four days time although there is no evidence of fibrosis by histopathological criteria.

(2) After 12 days of DBT treatment $(20 \mathrm{mg} / \mathrm{kg})$, there was extensive mononuclear and polymorphonuclear cell infiltration in portal tracts, particularly in and around bile ducts, and within the parenchyma. Unlike other forms of drug-induced hepatic injury, the central vein areas were preserved. There were focal and confluent areas of necrosis, infarcted areas, nonspecific granulomatous lesions and an accumulation of fibrous tissue. 
Increased collagen content was also reflected by the two-fold increase in hydroxyproline content. Prolyl hydroxylase activity was elevated only $50 \%$ over controls and in vitro collagen synthesis was unchanged after 12 days of treatment. However, percent collagen synthesis was increased two-fold.

(3) DBT $\left(3 \times 10^{-7}\right.$ and $\left.3 \times 10^{-6} \mathrm{M}\right)$ had no effect on prolyl hydroxylase activity of mouse fibroblasts in cell culture.

(4) These results suggest that DBT-induced fibrogenesis is not a result of direct stimulation of fibroblasts and that biliary damage and/or inflammatory processes are responsible for increased fibrogenesis and associated histopathological changes. 
REFERENCES

Aldridge, W.N. and Cremer, J.E.: The biochemistry of organotin compounds: diethyltin dichloride and triethyltin sulfate. Biochem. J. 61, 406-418, I955.

Aldridge, W.N. and Street, B.W.: Oxidative phosphorylation: biochemical effects and properties of trialkyltins. Biochem. J. 21: 287-297, 1964.

Aldridge, W.N. and Street, B.W.: Oxidative phosphorylation: the specific binding of trimethyltin and triethyltin to rat liver mitochondria. Biochem. J. 118: 171179. 1970.

Aldridge, W.N. and Street, B.W.: oxidative phosphorylation: the relation between the specific binding of triethyltin and trimethyltin to mitochondria and the ir effects on various mitochondrial function. Biochem. J. 124. 221-234, 1971 .

Aterman, K.: Studies in fibrosis of the liver induced by carbon tetrachloride (I) relation between hepatocellular injury and new formation of fibrous tissue. Arch. Pathol. 57: $1-11,1954$.

Barnes, J.M. and Magee, P.N.: The biliary and hepatic lesion produced experimentally by dibutyltin salts. J. Path. Bact. 25: 267-279, 1958.

Barnes, J.M. and Stoner. H.B.: Toxic properties of some dialkyl and trialkyl tin salts. Br. J. Ind. Med. 15: 15-23. 1958.

Barnes, J.M. and Stoner, H.B.: The toxicology of tin compounds: Pharmacol. Rev. 18, 211-231, 1961.

Bornstein, P.8 The biosynthesis of collagen. Ann. Rev. Biochem. 43: 567-603, 1974 .

Brunner, G., Perings, E., and Creutzfeldt, W.: D-peñicillamine in experimental cirrhosis. Collagen Metäbolism in the Liver. ed. by H. Popper and $\mathrm{K}$. Becker. Medical Book Corp. Stratton Intercontinental, New York. 1975. 
Cameron, G.R , and Karunaratne, W.A.: Carbon tetrachloride cirrhosis in relation to liver regeneration. J. Path. Bact. 42: 1-22, 1936.

Chen, T.S.N. and Leevy, C.M.: Collagen biosynthesis in liver disease of the alcoholic. J. Lab. Clin. Med. 85: 103-112, 1975.

Chichester, C.O., Fuller, G.C. and Cardinale, G.J.s In vivo labeling and turnover of prolyl hydroxylase and a related immunoreactive protein. Biochem. Biophys. Res. Commun. 23: 1056-1062, 1976.

Crystal, R.G.1 Lung collagen: definition, diversity, and development. Fed. Proc. 33: 2248-2255, 1974.

Diegelmann, R.F., Rothkopf, L.C. and Cohen, I.K.: Measurement of collagen biosynthesis during wound healing. J. Surg. Res. 19, 239-243, 1975.

Fujiwara, K., Sakai, T., Oda, T. and Igarashi, S.: The presence of collagenase in Kuppfer cells of the rat liver. Biochem. Biophys. Res. Commun. 54: 531-537. 1973.

Fuller, G.C., Nolan, J.C., Fink, S., and Rodil, F.V.i Prolyi hydroxylase activity in normal and diseased human liver. Proc! Soc. Exp. Biol. Med. 151: 61-64, 1976.

Füller, G.C., Vidins, E.I. and Rodil, F.V.: Liver prolyl hydroxylase as an indicator of fibrogenesis in alcoholic cirrhosis. Alcohol and Aldehyde Metabolizing Systems. eds. R.C. Thurman, J.R. Williams on, H. Drout and B. Chance. Academic Press, New York, 1977.

Gaunt, I.F., Colley, J., Grasso, P., Creasy, M. and Gangolli, S.D.: Acute and short-term toxicity studies on dibutyltin dichloride in rats. Food. Cosmet. Toxicol. 6: 599-608, 1968 .

Goldberg, B., Taubman, M.B. and Radin, A.: Procollagen peptidase: its mode of action on the native substrate. Cell 4. 45-50, 1975.

Gribble, T.J., Comstock, J.P. and Udenfriend Collagen chain formation and peptidyl proline hydroxylastion in monolayer tissue cultures of $L 929$ fibroblasts. Arch. Biochem. Biophys. 129, 308-316, 1969. 
Guess, W.L. and Haberman, S.: Toxicity profiles of vinyl and polyolefinic plastics and their additives. J. Biomed. Mater. Res. 2. 313-335, 1968.

Guess, W.L. and Stetson, J.B.: Tissue reactions to organotin-stabilized polyvinylchloride catheters. JAMA 204, 118-122 1968.

Huberman, A., Recio, A.: and Rojkind, M.: Collagen biosynthesis in normal and cirrhotic rat liver slices. Proc. Soc. Exptl. Biol. Med. 131, 200-2-3, 1969.

Hutton, J.J., Tappe I, A.L.: and Udenfriend, S.: A rapid assay for collagen proline hydroxylase. Anal. Biochem. 16: 384-394, 1966 .

Kent, G., Fels, I.G., Dubin, A. and Popper, H. ' Collagen content based on hydroxyproline determinations in humain and rat livers: its relation to morphologically demonstrable reticulum and collagen fibers. Lab. Invest. $\underline{8}$ $48-55,1959$.

Kent, G., Gay, S., Inouye, T., Bahy, R., Minick, O.T. and Popper, H.: Vitamin A-containing lipocytes and formation of type III collagen in liver injury. Proc. Natl. Acad. Sci. 23: 3719-3722, 1976.

Kershenobich, D., Ferro, F.J. and Rojkind, M.: The relationship between the free pool of proline and collagen content in human liver cirrhosis. J. Clin. Invest. 49: 2246-2249, 1970.

Kivirikko, K.I., Laitinen, 0, and Prockop, D.J.: Modifications of a specific assay for hydroxyproline in urine. Anal. Biochem. 19, 249-255, 1967.

Langness, U. and Udenfriend, S. Collagen biosynthesis in nonfibroblastic cell lines. Proc. Natl. Acad. Sci. 71: $50-51,1974$.

Lapiere, C.M., Lenders, A. and Kohn, L.D.: Procollagen peptidase an enzyme excizing the coordination peptides of collagen. Proc. Natl. Acad. Sci. 68: 3054-3058, 1971 .

Leevy, C.M., Popper. H. and Sherlock. S. (criteria committee): Diseases of the Liver and Biliary Tract: Standardization of Nomenclature, Diagnostic Criteria and Diagnostic Methodology. Fogarty International Center 
Proceedings, No. 22, D.H.E.W. Publication No. (N.I.H.) 76-725, U.S. Govt. Printing Office, Wash, D.C.. 1976.

Madden, J.W., Gertman, P.M. and Peacock, E.E.: Dimethylnitrosamine-induced hepatic cirrhosis a new canine model of an ancient human disease. Surgery 68, 260268. 1970.

Magee, P.N., Stoner, H.B. and Barnes, J.M.: The experimental production of edema in the central nervous system of the rat by triethyltin compounds. J. Path. Bact. 23: 107-126. 1957.

Miller, E.J.: Biochemical characteristics and biological significance of the genetically-distinct collagens. Mol. Cell. Biochem. 13, 165-192, 1976.

Montfort, I. and Perez-Tamayo, R.: The distribution of collagenase in normal rat tissues. J. Histochem. Cytochem. 23:910-920, 1975.

Nimni, M.: Sensitive biological tests for medical grade plastics. I. Toxicity of organotin stabilizers. J. Pharm. Sci. 53, 1262-1264, 1964.

Okazaki, I. and Maruyama, K.: Collagenase activity in experimental hepatic fibrosị. Nature 252, 49-50, 1974.

Paronetto, F, and Popper, H.: Chronic liver injury induced by immunologic reactions: cirrhosis following immunization with heterologous sera. Am. J. Path. 49: 1087-1101. 1966.

Piver, W.T.: Organotin compounds: "industrial applications and biological investigation. Environ. Health. Perspect. 4: 61-80, 1973.

Popper, H.: Overview of past and future of collagen metabolism. Collagen Metabolism in the Liver. ed. by H. Popper and K. Becker, Médical Book Corp. Stratton Intercontinental. New York, 1975.

Popper, H. and Udenfriend, S.: Hepatic fibrosis: correlation of morphological and biochemical investigations. Am. J. Med. 49, 707-721, 1970.

Prockop, D.J. and Juva, K.: Synthesis of hydroxyproline in vitro by the hydroxylation of proline in a precursor of collagen. Proc. Natl. Acad. Sci. U.S.A. 53: 661-668, 1965 . 
Rhoads, R.E. and Udenfriend, S.: Purification and properties of collagen proline hydroxylase from newbirn rat skin. Arch. Biochem. Biophys. 139, 329-339, 1970.

Rojkind, M.: Inhibition of liver fibrosis by L-azetidine-2-carboxylic acid in rats treated with carbon tetrachloride. J. Clin. Invest. 52, 2451-2456, 1973.

Rojkind, J, and Diaz De Leon, I.: Collagen biosynthesis in cirrhotic rat liver slices a regulatory mechanism. Biochim. Biophys. Acta. 217: 512-522, 1970.

Seigel, R.C., Pinnell, S.R. and Martin, G.R.: Crosslinking of collagen and elastin: Properties of lysyl oxidase. Biochemistry 2: 4486-4492, 1970.

Sinex, F.M., Van Slyke, D.D. and Christman, D.R.: The source and state of the hydroxylysine of collagen. II failure of free hydroxylysine to serve as a source of the hydroxylysine or lysine of collagen. J. Biol. Chem. 234. 918-921, 1959.

Speakman, P.T.: Proposed mechanism for the biological assembly of collagen triple helix. Nature 229: 241243. 1971 .

Spiro, M.J. and Spiro, R.G.: Studies on the biosynthesis of the hydroxylysine-linked disaccharide unit of basement membranes and collagen. II Kidney galactosyltransferase. J. Biol. Chem. 246, 4910-4918, 1971.

Spiro, R.G. and Spiro, M.J.: Studies on the biosynthesis of the hydroxylysine-linked disaccharide unit of basement membranes and collagen. I Kidney gluc osyltransferase. J. Biol. Chem. 246: 4899-4909, 1971.

Spiro, R.G. and Spiro, M.J.: Studies on the biosynthesis of hydroxylysine-linked disaccharide unit of basement membranes and collagen. III Tissue and subceliular distribution of glycosyltransferases and the effect of various conditions on the enzyme levels. J. Biol.Chem. 246: 4919-4925, 1971.

Stone, N, and Meister, A.s Function of ascorbic acid in the conversion of proline to collagen hydroxyproline. Nature 194: 555-557, 1962. 
Stoner, H.B., Barnes, J.M. and Duff, J.I.: Studies on the toxicity of alkyl tin compounds. Brit. J. Pharmacol. 10: 16-25, 1955 .

Takuechi, T., Kivirikko, K.I. and Prockop, D.J. . Increased protocollagen hydroxylase activity in the livers of rats with hepatic fibrosis. Biochim. Biophys. Res. Comm. 28: 940-944, 1967.

Tan, L.P. and $\mathrm{Ng}, \mathrm{M} . \mathrm{I} . \mathrm{s}$ The toxic effects of trialkyltin compounds on nerve and muscle. J. Neurochem. 29: $689-696,1977$. 


\section{VITA}

Jeannee $\mathrm{K}$. Yermakoff was born on October 28, 1952 in Jersey City, New Jersey. Ms. Yermakoff received her Bachelor of Science degree with honors in Chemistry in 1975. At that time Ms. Yermakoff began her graduate education at the University of Rhode Island in the Department of Pharmacology and Toxicology and completed the requirements for Master of Science degree in May 1978. During her graduate training, Ms. Yermakoff received Teaching Assistantships from the Department of Pharmecology and the Affirmative Action Program of the University of Rhode Island Graduate School.

Ms. Yermakoff will continue her graduate education at the University of Rhode Island in the Department of Pharmacology and Toxicology where she will.work for the Doctor of Philosophy Degree in Pharmacology. 